\title{
THE RELEVANCE OF AUTOTRONIC ENGINEERING COMPETENCE AT VOCATIONAL HIGH SCHOOL TO THE WORLD OF WORK
}

\author{
Yudha Ari Purnama ${ }^{1 *}$, Wagiran ${ }^{1}$ \\ ${ }^{1}$ Universitas Negeri Yogyakarta
}

Jl. Colombo No. 1, Karangmalang, Depok, Sleman, Yogyakarta 55281, Indonesia

\begin{abstract}
This research aims to reveal: (1) the competencies profile of autotronic engineering at vocational high school; (2) the competencies profile of autotronic engineering required by the world of work; and (3) the description of relevance between the competencies profile of autotronic engineering at vocational high school and the competencies profile of autotronic engineering required by the world of work. This research was quantitative research with survey method. This research used descriptive analysis as a data analysis method. The results of this research are as follows. (1) There are 13 competency items in Support of Autotronic System cluster taught at vocational high school and required by the world of work, with a percentage of $81 \%$ out of $85 \%$ (irrelevant). (2) There are 34 competency items in Engine Management System cluster taught at vocational high school and required by the world of work, with a percentage of $70 \%$ out of $67 \%$ (relevant). (3) There are 44 competency items in the Chassis Management System cluster taught at vocational high school and required by the world of work, with a percentage of $70 \%$ out of $60 \%$ (relevant). (4) There are 37 competency items in the Comfort, Safety, and Information Technology cluster taught at vocational high school and required by the world of work, with a percentage of 52\% out of $63 \%$ (irrelevant). (5) There are four competency items in the Vehicle Control System Cluster taught at vocational high school and required by the world of work, with a percentage of $27 \%$ out $59 \%$ (irrelevant).
\end{abstract}

Keywords: autotronic engineering, vocational high school, world of work

How to cite: Purnama, Y., \& Wagiran, W. (2020). The relevance of autotronic engineering competence at vocational high school to the world of work. Jurnal Pendidikan Vokasi, 10(3), 300-314. doi:https://doi.org/10.21831/jpv.v10i3.33332

*Corresponding Author: Yudha Ari Purnama yudha.aripurnama1991@gmail.com Department of Technology and Vocational Education, Graduate School, Universitas Negeri Yogyakarta Jl. Colombo No. 1, Karangmalang, Depok, Sleman, Yogyakarta 55281, Indonesia 


\section{INTRODUCTION}

"The world of work is cosntantly changing and must always change because of the dynamic process of human life" (Sudira, 2016, p. 68). Every individual will surely encounter problems in meeting various kinds of life necessities. Therefore, humans then develop technology to help themselves meet each of their needs effectively and efficiently. The development of the technology also changes the characteristics of the world of work in which their technologies are applied. Indeed, it is proper to say that the dynamic needs of human life can change the characteristics of the world of work. In addition, Rojewski (2009, p. 19) believes that

"unprecendented changes in work, family, community, and political life in the twenty-first century-fuelled by myriad phenomena such as globalisation, market deregulation, the worldwide influence of capitalism, and a need for knowledgeable workers skilled in information technologies-confront people in every region of the world of the world".

However, changes in characteristics of the world of work have major influence on other aspects of human life as well, that is the need for relevant competencies to the changes. Sudira (2016, p. 67) states "characteristics changes in the world of work have a direct implication on the need for developing work competencies". Lucas et al. (2012, p. 38) define competency as "the capability to perform and use knowledge, skills, and attitudes...”. MacKenzie and Polvere $(2009$, p. 63) define competency as "the individual's demonstrated capacity to perform, i.e. the possession of knowledge, skills, and personal characteristics needed to satisfy the special demand or requirements of particular situation". Thus, competency is individual ability to perform to perform particular tasks and duties to the standard of performance expected in the workplace, applying all relevant skills, knowledge, and attitudes consistenly over time in the required workplace situations (International Labor Organization, 2015, p. ix).

Yet, there are few differences between competence and compe-tency. Norton $(1997$, p. 285) explains that

"(1) competence is achievement of the knowledge, skills, and attitudes required by worker in order to perform a given occupational task; while (2) competency is a description of the ability one possesses when they are able to perform a give occupational task effectively and efficiently".

"Competence refers to a person's capacity while competency refers to specific capabilities" (Zhao, 2014, p. 169). In addition, Sanghi (2007, p. 8) differentiates between competence and competency, as in Table 1.

Table 1. Differences between Competence and Competency

\begin{tabular}{cc}
\hline Competence & Competency \\
Skill-based & Behaviour-based \\
Standard attained & Manner of behaviour \\
What is measured & How the standard is achieved \\
\hline
\end{tabular}

Competences are packages of competencies, consisting of three components, i.e.: (1) knowledge; (2) attitude; and (3) skill, to perfom a given occupational tasks effectively and efficiently. Gagnon (2009, p. 2699) describes both of them as "Integrated collection of knowledge, know-how, know-how-to-be, and know-how-to-live-together that can be mobilized when needed, both successfully for others and for oneself, throughout life".

Technical and Vocational Education and Training (TVET), as a type of education closely related to the world of work, has responsibilities and roles in developing competencies relevant to the world of work. Hollander and Mar (2009, p. 41) state "TVET is concerned with the acquisition of knowledge and skills for the world of work". Sudira (2016, p. 69) states that one of the ways to develop competencies relevant to every change in the world of work is to use the learn, re-learn, and unlearn method. The meaning of the method is to know and learn what is still needed and must be learned, which means to learn competencies still relevant and useful, and to not learn competencies that are no longer relevant and useful. This is in line with Rojewski $(2009$, p. 19) who states 
"Technical and Vocational Educaion and Training (TVET) are particularly challenged to develop, adapt or redesign strategies to address the needs of workers and society".

The presence of Vocational High School as one of the formal channels TVET institutions in Indonesia is a sign that the development of the world of work in Indonesia is going well. Besides, UNESCO-UNEVOC (2015, pp. 6-8) states that formal TVET system in Indonesia is divided into two levels: (1) 'Senior Technical and Vocational Secondary School', or in Indonesia it is called Sekolah Menengah Kejuruan or 'SMK'; and (2) 'Higher Education', that are divided into five kind of institutions: (a) Academy; (b) Higher School; (c) Polytechnic; (d) Institute; and (e) University. According to international literatures, SMK is also called 'Senior Technical and Vocational Secondary School' (UNESCO-UNEVOC, 2015, p. 6), 'Vocationalized Secondary Education' (Lauglo, 2009, p. 2295), 'Vocational High School' (Newhouse \& Suryadarma, 2009, p. 5), etc. Lauglo (2009, p. 2295) defines SMK as "curriculum which remains overwhelmingly general or academic in nature, but which includes vocational or practical subjects as a minor portion of the students' timetable during the secondary school course".

One of the developments in the world of work that is happening rapidly in Indonesia is in the field of automotive engineering, especially in the vehicle electronics system sector, which came to be known as the autotronic engineering subsector.

“Just as phones got smart, so will cars. They won't quite think, but they will respond and remind. Cars on the road are being equipped with danger-warning applications, traffic information services, and host of infotainment features and increasingly safety features as well" (Advanced Industries, 2013, p. 14).

Robert Bosch GmBH (2007, p. 10) explains that "the amount of electronics in the vehicle has risen in recent years and is set to increase yet further in the future". Autotronic engineering is a combination field of work that combines automotive engineering with electronic engineering.

As a response to the development of autotronic engineering, the Ministry of Education and Culture through its decision in 2008 opened the Autotronic Engineering Major as a part of the Automotive Engineering Study Program. Furthermore, Na (2014, p. 109) states:

“... not only the TVET system allow individuals to enter the labour market with improved vocational capacities but also maintains job creation, promotes one's career development or even helps individuals to land in a better job. In other words, the TVET system is closely interconnected to employment. In particular, to respond to rapidly changing technology, re-training of employees or training to boost their capacities have recently been increasing. In accordance with it, the TVET system has recently been carried out in the field, reflecting the increasing number of the system users, rapid changes in the industries, etc., and education training institutes have been emphasized autonomy and cooperation with industries".

This program once was categorised into the Electronic Engineering Study Program because it has electronic engineering materials as its fundamental knowledge. However, in 2016, TOTR Major was officially determined in the category of Automotive Engineering Study Program through the Decree of the Director General of Primary and Secondary Education of the Ministry of Education and Culture Number 4678/D/KEP/MK/2016 concerning the Vocational Secondary Education Competence Spectrum, due to the realm of the world of work for Autotronice Engineering Major is in automotive engineering.

Hence, the Automotive Engineering Study Program is based on the Regulation of the Director General of Primary and Secondary Education of the Ministry of Education and Culture Number 06/D.D5/KK/2018, which states that the Competence Spectrum of Vocational High School/Islamic Vocational High School has seven majors, namely: (1) Automotive Light Vehicle Engineering (ALVE); (2) Motorcycle Business and Engineering (MBE); (3) Heavy Equipment Engineering (HEE); (4) Automotive Body Engineering (ABE); (5) Autotronic Engineering (AE); (6) Automotive Maintenance Management and Engineering (AMME); (7) Automotive Torque and Energy Conversion (ATEC).

Since its opening in 2008 until 2019, the establishment of AE Major in vocational schools is arguably not going well. Learning material that is combination between electronic engineering and 
automotive engineering makes AE Major quite difficult to absorb and understand completely by students in quite short time (three years). In addition, referring to the car actual condition, the practice unit that is needed for Teaching and Learning Process (TLP) is fairly sophisticated and certainly requires a significant amount of cost for the SMK to be able to have it for learning purposes.

For the Central Java region, compared to other majors that focus on cars as well, such as ALVE Major and ABE Major, AE Major has the least number of SMK that holding the major. The data recorded on the site of SMK Main Data (Regulation of the Director General of Primary and Secondary Education of the Ministry of Education and Culture Number 06/D.D5/KK/2018, 2018) are presented in Table 2.

Table 2. Automotive Engineering SMK in Central Java

\begin{tabular}{|c|c|c|c|}
\hline \multirow{2}{*}{ Majors } & \multicolumn{2}{|c|}{ SMK Status } & \multirow{2}{*}{ Number of SMK } \\
\hline & Public & Private & \\
\hline ALVE & 100 & 423 & 523 \\
\hline MBE & 58 & 349 & 407 \\
\hline $\mathrm{HEE}$ & 1 & 3 & 4 \\
\hline ABE & 12 & 19 & 31 \\
\hline $\mathbf{A E}$ & 6 & 12 & 18 \\
\hline AMME & 4 & 2 & 6 \\
\hline ATEC & - & - & - \\
\hline \multicolumn{3}{|c|}{ Total } & 989 \\
\hline
\end{tabular}

One of the SMK that have difficulty in implementing and applying AE Major into TLP is SMK Ma'arif Salam located in Magelang Regency. SMK Ma'arif Salam is the only SMK that runs AE Major in the entire City and Regency of Magelang. SMK Ma'arif Salam is located at Citro Gaten Street, Salam, Salam District, Magelang Regency, Central Java, 56484. SMK Ma'arif Salam has five majors, as presented in Table 3.

Table 3. Majors at SMK Ma'arif Salam

\begin{tabular}{ccc}
\hline Name of SMK & Majors & Status \\
\hline & ME & A \\
SMK Ma'arif Salam & ALVE & A \\
& MBE & Not accredited yet \\
& AE & B acredited yet \\
\hline
\end{tabular}

The AE Major was first established at SMK Ma'arif Salam in 2013 and has graduated students four times, in 2016, 2017, 2018 and 2019. During the implementation since 2013, AE Major at SMK Ma'arif Salam experienced very fluctuating statistics in student admission and graduation. Data from SMK Ma'arif Salam tracer studies show that AE Major in 2016 graduated 42 students and in 2017 graduated 25 students. There is a big difference between the number of first graduates in 2016 and second graduates in 2017. Then, one of the vocational teachers responsible for the New Students Admission Program (NSAP), said that in the 2018/2019 academic year only 15 students registered out of 33 available quota and in 2019/2020 only 25 out of 36 available quota.

The issue was responded by one of AE Major teachers at SMK Ma'arif Salam. He stated that not many people knew and understood what and how the essence of autotronic engineering actually was. So far, the knowledge of ordinary people about the field of automotive engineering is more inclined to the ALVE Major. Even the teachers who teach at AE Major itself also did not fully know and understand the autotronic engineering in depth and thoroughly. Their educational background from college were ALVE Major. However, due to the needs of teachers, they needed to teach in AE Major, they were given training to be able to teach in AE Major optimally.

Each student in grade XII always goes through the Competencies Examination (CE) at the end of even semester, including students of AE Major at SMK Ma'arif Salam. The researchers observed when SMK Ma'arif Salam held CE for students of grade XII AE Major. The researchers were given the opportunity to observe the implementation of CE directly from close quarters, even 
had time to give advice and assessments to students of grade XII AE Major who underwent the CE. From the observations, the level of competence of students of grade XII AE Major at SMK Ma'arif Salam were at the following levels: (a) drawing electronic wiring of autotronic system units; (b) assembling electronic wiring on a practice board; (c) conducting analysis and diagnosis of car condition using scantool.

Besides, referring to Indonesia's National Work Competencies Standard (INWCS), Core Competencies and Basic Competencies (CC \& BC), and Indonesia's National Qualification Framework (INQF) Schematic of Autotronics Engineering as the chosen guidelines of the application of competencies in TLP at SMK Ma'arif Salam, the competencies that must be mastered and completed by AE Major students are not just these three competencies. However, the competencies that must be completed by students of the AE Major SMK Ma'arif Salam also include maintenance, analysis, diagnosis, repairing, drawing and assembling the wiring, as well as the ability to read, understand, and then translate data generated by diagnostic aid tools in autotronic system.

An AE Major teacher said the condition of the infrastructure for practicing owned by the AE Major at SMK Ma'arif Salam (ed. 2017 to 2019) is still far from the actual conditions of the workplace. Therefore, with these conditions, AE Major at SMK Ma'arif Salam is still not able to apply all the competencies recorded in the competency guidelines, especially $\mathrm{CC}$ and $\mathrm{BC}$ of $\mathrm{AE}$ Major, optimally. The AE Major at SMK Ma'arif Salam have to sort out and choose which items of the autotronic engineering competence can be applied optimally with such conditions, based on the Decree of the Director General of Primary and Secondary Education of the Ministry of Education and Culture Number 330/D.D5/KEP/KR/2017 concerning the Core Competencies and Basic Competencies, the guidelines containing competency points specifically intended for use in TLP of SMK/ MAK.

At the end of 2017, SMK Ma'arif Salam changed its status from Referenced SMK to Profession Certification Body-P1/Lembaga Sertifikasi Profesi-P1 (LSP-P1). The status certainly demands SMK Ma'arif Salam as a whole to fix and improve every aspect in shortages. One way that could be done was the relevance method, which not only affects the quality of TLP but also can have a positive impact on the quality of practice infrastructures and graduates. The relevance process was done periodically according to changing characteristics in the world of work. Thus, through this research, the researchers intend to reveal the implementation of the relevance of Autotronic Engineering competence at SMK Ma'arif Salam to the world of work. It is expected to reveal the gap between autotronic engineering competencies taught at SMK Ma'arif Salam and autotronic engineering competencies required by the world of work.

The researches about relevance of SMKs majors in the automotive engineering field to the world of work are generally conducted mostly not on AE Major, such as Priyatama and Sukardi's (2013) research on ALVE Major, Jatmoko's (2013) research on ALVE Major, and Yudantoko and Arifin's (2016) research on ABE Major. As known and studied, there has been no study that discusses the relevance of AE Major with the world of work yet, especially in Indonesia. Most studies related to AE Major discuss the development of learning media, analysis of the availability of practice infrastructures, or the application of learning models, like in Fatullah and Ismara's (2018) research, Santoso's (2015) research, or Said et al. (2016) research.

\section{RESEARCH METHOD}

This research was conducted with a quantitative approach employing a descriptive research method. "The aim of quantitative research is to collect explanation about how significant the hypotheses as already formulated answers" (Indrawan \& Yaniawati, 2016, p. 51). Therefore, this study aims to reveal the following variables: (1) the profile of autotronic engineering competencies that is taught at SMK Ma'arif Salam; (2) the profile of the autotronic engineering competencies required by the world of work; (3) the description of relevance between the profile of autotronic engineering competencies taught at SMK Ma'arif Salam and the profile of autotronic engineering competencies required by the world of work.

This research was carried out at SMK Ma'arif Salam and in ten car workshops, namely: Bona, GaMa, Hyundai, KIA, MADINA, Mercedes-Benz, Mitsubishi, Mot-Tronic, Suzuki, and 
Toyota. The study was conducted in more than one month from mid-November to the end of December 2019. The research subjects in this study were three teachers of AE Major at SMK Ma'arif Salam and ten representatives from the ten different workshops. The ten workshop representatives are the Head of Mechanics, Head of Workshop, Service Advisor, Service Manager, and Workshop Owner.

The used data collection methods were unstructured interviews, observations, and document studies, while the used research instrument was a Guttman Scale checklist questionnaire (0 and 1). The checklist questionnaire was made from the items of autotronic engineering competencies that were originated from a combination of SKKNI, KI and KD, and the KKNI Scheme of Autotronic Engineering, and were developed using Anderson's revised Bloom Taxonomy as its foundation. The checklist questionnaire divides competency points into three clusters, as follows: (1) Support of Autotronic System (SAS); (2) Engine Management System (EMS); (2) Chassis Management System (CMS); (3) Comfort, Safety, and Information Technology (CSIT); and (5) Vehicle Control System (VCS).

The instrument validity was conducted only by expert validity, because the items were taken from the standard competency guidelines. The result of expert validity states that the instrument was valid and ready to use. Instrument reliability was carried out with the help of the IBM SPSS 23.0 program and the results were obtained as presented in Table 4.

Table 4. Reliability Test Result

\begin{tabular}{ccc}
\hline No & Cluster & Alpha Value \\
\hline 1 & SAS & 0.843 \\
2 & EMS & 0.974 \\
3 & CMS & 0.988 \\
4 & CSIT & 0.986 \\
5 & VCS & 0.970 \\
\hline
\end{tabular}

Referring to Table $\mathrm{r}$ with the number of $\mathrm{n}$ as many as 13 people, then the alpha value of Table $r$ is 0.576 . Then, it indicated that all the competencies clusters of autotronic engineering and research instruments are reliable. The data analysis method used was comparative descriptive analysis technique with the help of IBM SPSS 23.0 and Microsoft Excel 2019 programs. Data analysis was performed in order to obtain the frequency distribution of competency items per cluster and frequency distribution of percentage items of competency per cluster. Because the Guttman Scale instrument only has two answer options ( 0 and 1$)$, the mean value of the percentage of competency items per cluster was used as the middle value and the separator of the competency item status obtained.

\section{RESULTS AND DISCUSSION}

\section{Results}

\section{Support of Autotronic System (SAS) Cluster}

In the SAS cluster, there are 13 competency items that are taught in the TOTR Major of SMK Ma'arif Salam and are required by the world of work out of 16 competency items required by the world of work, with the relevance percentage $81 \%$ out of standard $85 \%$. Then, the SAS cluster is stated to be relevant. Table 5 shows the description of the SAS cluster competency items that are taught in the AE Major at SMK Ma'arif Salam and required by the world of work. Details of these competency items are presented in the form of a Pie diagram, shown in Figure 1.

There are 13 competencies of SAS Cluster that are taught at SMK Ma'arif Salam and required by the world of work. There are two competencies of SAS Cluster that are taught at SMK Ma'arif Salam but not required by the world of work. There are three competencies of SAS Cluster that are not taught at SMK Ma'arif Salam but required by the world of work. There are eight competencies of SAS Cluster that are not taught at SMK Ma'arif Salam and not required by the world of work. 
Table 5. Detail of SAS Cluster Relevance

\begin{tabular}{|c|c|c|}
\hline No & Core Competencies & Basic Competencies \\
\hline 1 & $\begin{array}{l}\text { Using diagnostic aid tool 'multimeter' for } \\
\text { autotronic engineering work }\end{array}$ & $\begin{array}{l}\text { - Identifying diagnostic aid tool 'multimeter' for } \\
\text { autotronic engineering work } \\
\text { - Understanding multimeter operate procedur } \\
\text { - Maintaining multimeter } \\
\text { - Operating multimeter } \\
\text { - Callibrating multimetr } \\
\text { - Analysing multimeter measurement result }\end{array}$ \\
\hline 2 & $\begin{array}{l}\text { Using diagnostic aid tool 'scantool' for } \\
\text { autotronic engineering work }\end{array}$ & $\begin{array}{l}\text { - Using diagnostic aid tool 'scantool' for autotronic } \\
\text { engineering work } \\
\text { - Understanding scantool operating procedure } \\
\text { - Operating scantool } \\
\text { - Analysing scantool measurement result }\end{array}$ \\
\hline 3 & $\begin{array}{l}\text { Using diagnostic aid tool 'oscilloscope' for } \\
\text { autotronic engineering work }\end{array}$ & - \\
\hline 4 & $\begin{array}{l}\text { Electric and Electronic Fundamentals for } \\
\text { Automotive (EEFA) }\end{array}$ & $\begin{array}{l}\text { - Identifying EEFA wiring components } \\
\text { - Understanding EEFA wiring work principles } \\
\text { - Reading EEFA wiring diagram }\end{array}$ \\
\hline
\end{tabular}

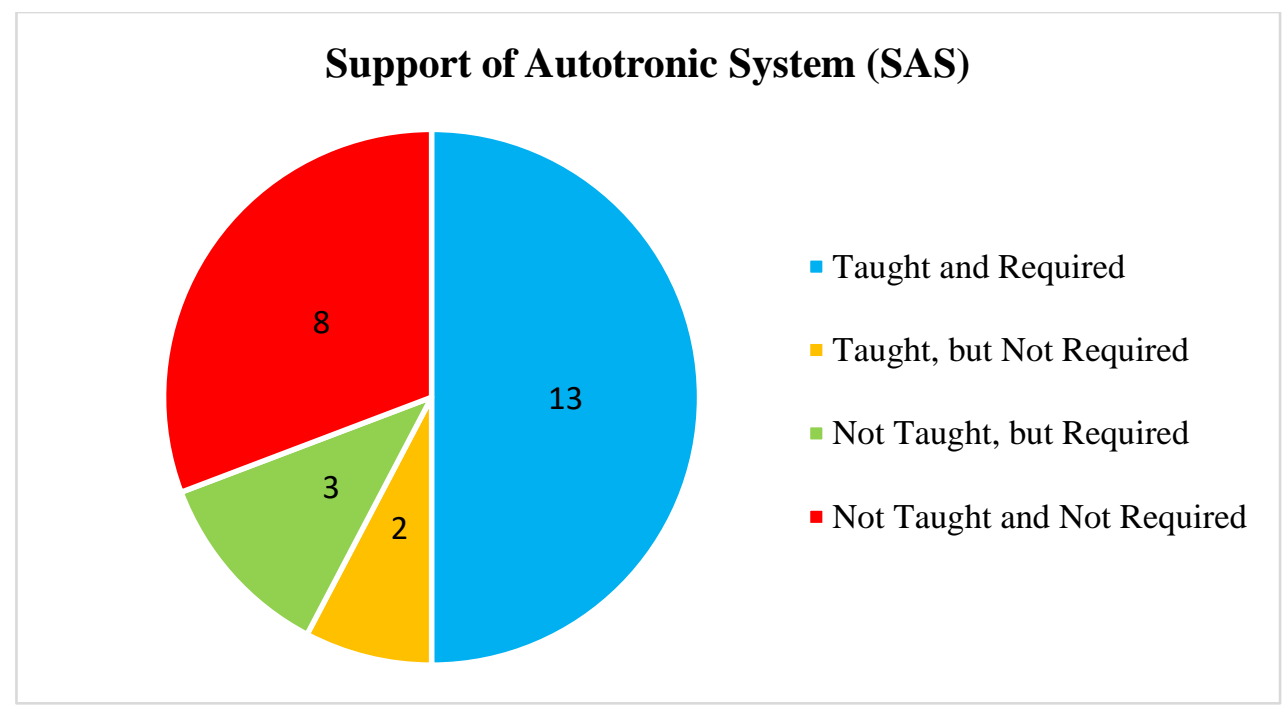

Figure 1. The Relevance of SAS Cluster

\section{Engine Management System (EMS) Cluster}

In the EMS cluster, there are 34 items of autotronic engineering competence that are taught in the TOTR Competency of SMK Ma'arif Salam and are required by the world of work out of the 49 competencies that are required by the world of work, with the relevance percentage of $70 \%$ from the $67 \%$ standard. Then, the EMS cluster is stated to be relevant. Table 6 shows a breakdown of the EMS cluster autotronic engineering competencies that are taught in the AE Major at SMK Ma'arif Salam and are required by the world of work. The details of these competency items can be presented in the form of a Pie diagram, as shown in Figure 2.

There are 34 competencies of EMS Cluster that are taught at SMK Ma'arif Salam and are required by the world of work. There are five competencies of EMS Cluster that are taught at SMK Ma'arif Salam but are not required by the world of work. There are 15 competencies of EMS Cluster that are not taught at SMK Ma'arif Salam but are required by the world of work. There are 36 competencies of SAS Cluster that are not taught at SMK Ma'arif Salam and are not required by the world of work. 
Table 6. Detail of EMS Cluster Relevance

\begin{tabular}{|c|c|c|}
\hline No & Core Competencies & Basic Competencies \\
\hline 1 & Electronic Control Ignition System (ECIS) & $\begin{array}{l}\text { - Identifying unit components } \\
\text { - Understanding the working principles and the } \\
\text { function of unit components } \\
\text { - Taking care of units and unit components } \\
\text { - Repairing damage to the unit } \\
\text { - Analyze symptoms of unit damage } \\
\text { - Diagnosing damage to the unit } \\
\text { - Testing unit work }\end{array}$ \\
\hline 2 & Electronic Starter Control System (ESCS) & $\begin{array}{l}\text { - Identifying unit components } \\
\text { - Understanding the working principle and the } \\
\text { functions unit component } \\
\text { - Drawing a series of units } \\
\text { - Taking care of units and unit components } \\
\text { - Repairing damage to the unit } \\
\text { - Analyzing symptoms of unit damage } \\
\text { - Diagnosing damage to the unit } \\
\text { - Testing unit work }\end{array}$ \\
\hline 3 & $\begin{array}{l}\text { Gasoline Engine Management System } \\
\text { (GEMS) }\end{array}$ & $\begin{array}{l}\text { - Identifying unit components } \\
\text { - Understanding the working principles and the } \\
\text { function of unit components } \\
\text { - Repairing damage to the unit } \\
\text { - Analyze symptoms of unit damage } \\
\text { - Diagnosing damage to the unit } \\
\text { - Testing unit work }\end{array}$ \\
\hline 4 & Diesel Engine Management System (DEMS) & $\begin{array}{l}\text { - Identifying unit components } \\
\text { - Understanding the working principles and the } \\
\text { function of unit components } \\
\text { - Repairing damage to the unit } \\
\text { - Analyze symptoms of unit damage } \\
\text { - Diagnosing damage to the unit } \\
\text { - Testing unit work }\end{array}$ \\
\hline 5 & Emission Control System (ECS) & $\begin{array}{l}\text { - Identifying unit components } \\
\text { - Understanding the working principles and the } \\
\text { function of unit components } \\
\text { - Repairing damage to the unit } \\
\text { - Analyze symptoms of unit damage } \\
\text { - Diagnosing damage to the unit } \\
\text { - Testing unit work }\end{array}$ \\
\hline 6 & Electronic Control Valve System (ECVS) & - \\
\hline 7 & $\begin{array}{l}\text { Variable Cylinder Management System } \\
\text { (VCMS) }\end{array}$ & - \\
\hline 8 & Hybrid Powertrain System (HPS) & - \\
\hline 9 & Electric Vehicle Powertrain System (EVPS) & - \\
\hline 10 & Cruise System Control (CCS) & $\begin{array}{l}\text { - Identifying unit components } \\
\text { - Understanding the working principles and the } \\
\text { function of unit components }\end{array}$ \\
\hline
\end{tabular}




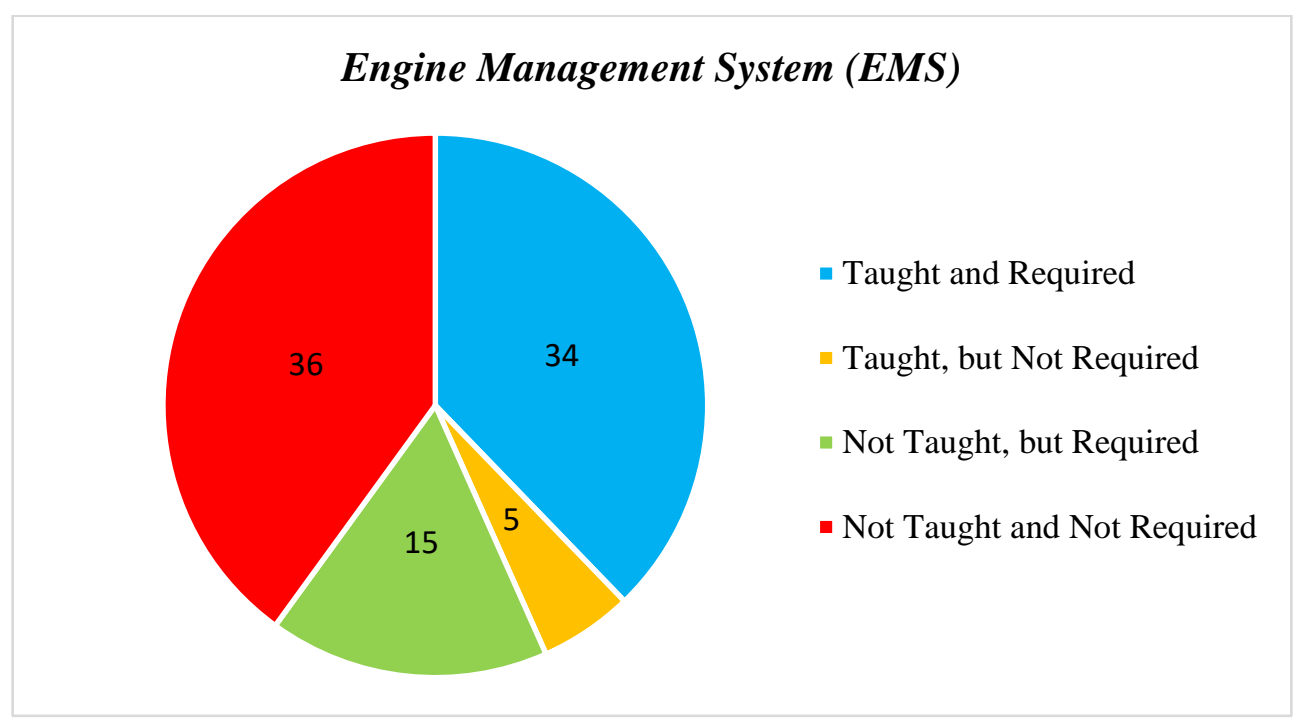

Figure 2. The Relevance of EMS Cluster

\section{Chassis Management System (CMS) Cluster}

In the CMS cluster, there are 44 items of autotronic engineering competencies that are taught in the AE Major at SMK Ma'arif Salam and are required by the world of work from 63 items of competence that are required by the world of work, with the relevance percentage of $70 \%$ of the $60 \%$ standard. Then, the CMS cluster is stated to be relevant. Table 7 shows a breakdown of the points of the CMS cluster autotronic engineering competency that is taught in the AE Major at SMK Ma'arif Salam and is required by the world of work. The details of these competency items are presented in a Pie Diagram as shown in Figure 3.

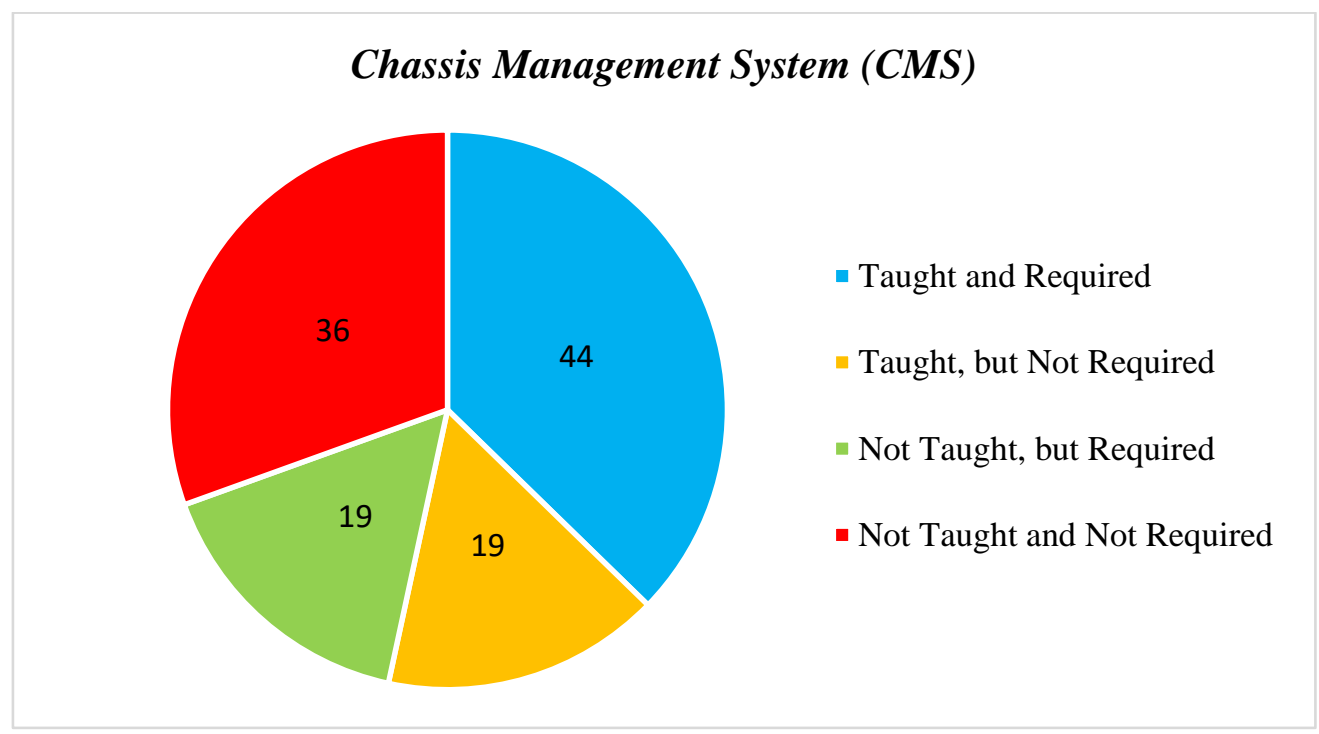

Figure 3. The Relevance of CMS Cluster

There are 44 competencies of CMS Cluster that are taught at SMK Ma'arif Salam and are required by the world of work. There are 19 competencies of CMS Cluster that are taught at SMK Ma'arif Salam but are not required by the world of work. There are 19 competencies of CMS Cluster that are not taught at SMK Ma'arif Salam but are required by the world of work. There are 36 competencies of CMS Cluster that are not taught at SMK Ma'arif Salam andare not required by the world of work. 
Table 7. Detail of CMS Cluster Relevance

\begin{tabular}{|c|c|c|}
\hline No & Core Competence & Basic Competence \\
\hline 1 & Anti-lock Brake System (ABS) & $\begin{array}{l}\text { - Identifying unit components } \\
\text { - Understanding the working principles and function of unit } \\
\text { components } \\
\text { - Taking care of units and unit components } \\
\text { - Repairing damage to the unit } \\
\text { - Analyze symptoms of unit damage } \\
\text { - Diagnosing damage to the unit } \\
\text { - Testing unit work }\end{array}$ \\
\hline 2 & $\begin{array}{l}\text { Traction Control System (TCS)/Anti Slip } \\
\text { Regulation (ASR) }\end{array}$ & $\begin{array}{l}\text { - Identifying unit components } \\
\text { - Understanding the working principles and function of unit } \\
\text { components }\end{array}$ \\
\hline 3 & Electronic Brake-force Distribution (EBD) & - Identifying unit components \\
\hline 4 & Electronic Stability Program (ESP) & $\begin{array}{l}\text { - Identifying unit components } \\
\text { - Understanding the working principles and function of unit } \\
\text { components } \\
\text { - Repairing damage to the unit } \\
\text { - Analyze symptoms of unit damage } \\
\text { - Diagnosing damage to the unit }\end{array}$ \\
\hline 5 & Hill-start Assist Control (HAC) & - \\
\hline & Hill Descent Control (HDC) & - \\
\hline 6 & Electric Parking Brake (EPB) & $\begin{array}{l}\text { - Identifying unit components } \\
\text { - Understanding the working principles and function of unit } \\
\text { components } \\
\text { - Taking care of units and unit components } \\
\text { - Repairing damage to the unit } \\
\text { - Analyze symptoms of unit damage } \\
\text { - Diagnosing damage to the unit }\end{array}$ \\
\hline 7 & Electro-Hydraulic Power Steering (EHPB) & $\begin{array}{l}\text { - Identifying unit components } \\
\text { - Understanding the working principles and function of unit } \\
\text { components } \\
\text { - Taking care of units and unit components } \\
\text { - Repairing damage to the unit } \\
\text { - Analyze symptoms of unit damage } \\
\text { - Diagnosing damage to the unit }\end{array}$ \\
\hline 8 & Electric Power Steering System (EPSS) & $\begin{array}{l}\text { - Identifying unit components } \\
\text { - Understanding the working principles and function of unit } \\
\text { components } \\
\text { - Taking care of units and unit components } \\
\text { - Repairing damage to the unit } \\
\text { - Analyze symptoms of unit damage } \\
\text { - Diagnosing damage to the unit } \\
\text { - Testing unit work }\end{array}$ \\
\hline 9 & $\begin{array}{l}\text { Electronic Control Automatic Transmission } \\
\text { (ECATS) }\end{array}$ & $\begin{array}{l}\text { - Identifying unit components } \\
\text { - Understanding the working principles and function of unit } \\
\text { components } \\
\text { - Taking care of units and unit components } \\
\text { - Repairing damage to the unit } \\
\text { - Analyze symptoms of unit damage } \\
\text { - Diagnosing damage to the unit }\end{array}$ \\
\hline 10 & Electronic Control Transaxle System (ECTS) & - \\
\hline 11 & $\begin{array}{l}\text { Electronic Control Suspension System } \\
\text { (ECSS) }\end{array}$ & $\begin{array}{l}\text { - Identifying unit components } \\
\text { - Understanding the working principles and function of unit } \\
\text { components } \\
\text { - Taking care of units and unit components }\end{array}$ \\
\hline 12 & Active Camber Control System (ACCS) & $\begin{array}{l}\text { - Identifying unit components } \\
\text { - Understanding the working principles and function of unit } \\
\text { components }\end{array}$ \\
\hline
\end{tabular}




\section{Comfort, Safety, and Information Technology (CSIT) Cluster}

Table 8. Details of CSIT Cluster Relevance

\begin{tabular}{|c|c|c|}
\hline No & Core Competencies & Basic Competencies \\
\hline 1 & Car Entertainment System (CES) & $\begin{array}{l}\text { - Identifying unit components } \\
\text { - Understanding the working principles and the } \\
\text { function of unit components }\end{array}$ \\
\hline 2 & Climate Control System (ClCS) & - \\
\hline 3 & Power Windows System (PWS) & $\begin{array}{l}\text { - Identifying unit components } \\
\text { - Understanding the working principles and the } \\
\text { function of unit components } \\
\text { - Caring for units and unit components } \\
\text { - Repairing damage to the unit } \\
\text { - Analyze symptoms of unit damage } \\
\text { - Diagnosing damage to the unit } \\
\text { - Testing unit work }\end{array}$ \\
\hline 4 & Power Door (open/close) System (PDS) & $\begin{array}{l}\text { - Identifying unit components } \\
\text { - Understanding the working principles and the } \\
\text { function of unit components } \\
\text { - Analyze symptoms of unit damage }\end{array}$ \\
\hline 5 & Power Sunroof System (PSRS) & - \\
\hline 6 & Electronic Mirror System (EMrS) & $\begin{array}{l}\text { - Identifying unit components } \\
\text { - Understanding the working principles and the } \\
\text { function of unit components } \\
\text { - Caring for units and unit components } \\
\text { - Analyze symptoms of unit damage } \\
\text { - Diagnosing damage to the unit } \\
\text { - Testing unit work }\end{array}$ \\
\hline 7 & Electronic Control Seat System (ECTSS) & - \\
\hline 8 & Electronic Control Pedal Adjusment System (ECPAS) & - \\
\hline 9 & Park Assist Control System (PACS) & $\begin{array}{l}\text { - Identifying unit components } \\
\text { - Understanding the working principles and the } \\
\text { function of unit components }\end{array}$ \\
\hline 10 & Auto Wash Wiper Control System (AWWCS) & $\begin{array}{l}\text { - Identifying unit components } \\
\text { - Understanding the working principles and the } \\
\text { function of unit components }\end{array}$ \\
\hline 11 & Lighting Control System (LCS) & $\begin{array}{l}\text { - Identifying unit components } \\
\text { - Understanding the working principles and the } \\
\text { function of unit components }\end{array}$ \\
\hline 12 & Central Door Lock System (CDLS) & $\begin{array}{l}\text { - Identifying unit components } \\
\text { - Understanding the working principles and the } \\
\text { function of unit components } \\
\text { - Caring for units and unit components } \\
\text { - Repairing damage to the unit } \\
\text { - Analyze symptoms of unit damage } \\
\text { - Diagnosing damage to the unit } \\
\text { - Testing unit work }\end{array}$ \\
\hline 13 & Alarm \& Immobilizer System (AIS) & $\begin{array}{l}\text { - Identifying unit components } \\
\text { - Understanding the working principles and the } \\
\text { function of unit components }\end{array}$ \\
\hline 14 & $\begin{array}{l}\text { Supplemental Restraint System (SRS) Airbag \& Safety } \\
\text { Belt }\end{array}$ & $\begin{array}{l}\text { - Identifying unit components } \\
\text { - Understanding the working principles and the } \\
\text { function of unit components } \\
\text { - Diagnosing damage to the unit }\end{array}$ \\
\hline 15 & Tire Pressure Monitoring System (TPMS) & - \\
\hline 16 & Panel Instrument System (PIS) & - \\
\hline 17 & Navigation System (NS) & - \\
\hline 18 & Multifunction Information Display (MID) & - \\
\hline
\end{tabular}


In the CSIT cluster, there are 37 items of autotronic engineering competencies that are taught in the AE Major at SMK Ma'arif Salam and are required by the world of work out of $71 \mathrm{com}$ petencies that are required by the world of work, with a relevance percentage of $52 \%$ from the $63 \%$ standard. Thus, the CSIT cluster is said to be irrelevant. Table 8 shows a breakdown of the points of the CSIT cluster autotronic engineering competencies that are taught in the AE Major at SMK Ma'arif Salam and are required by the world of work. Details of these competency items are shown in Figure 4.

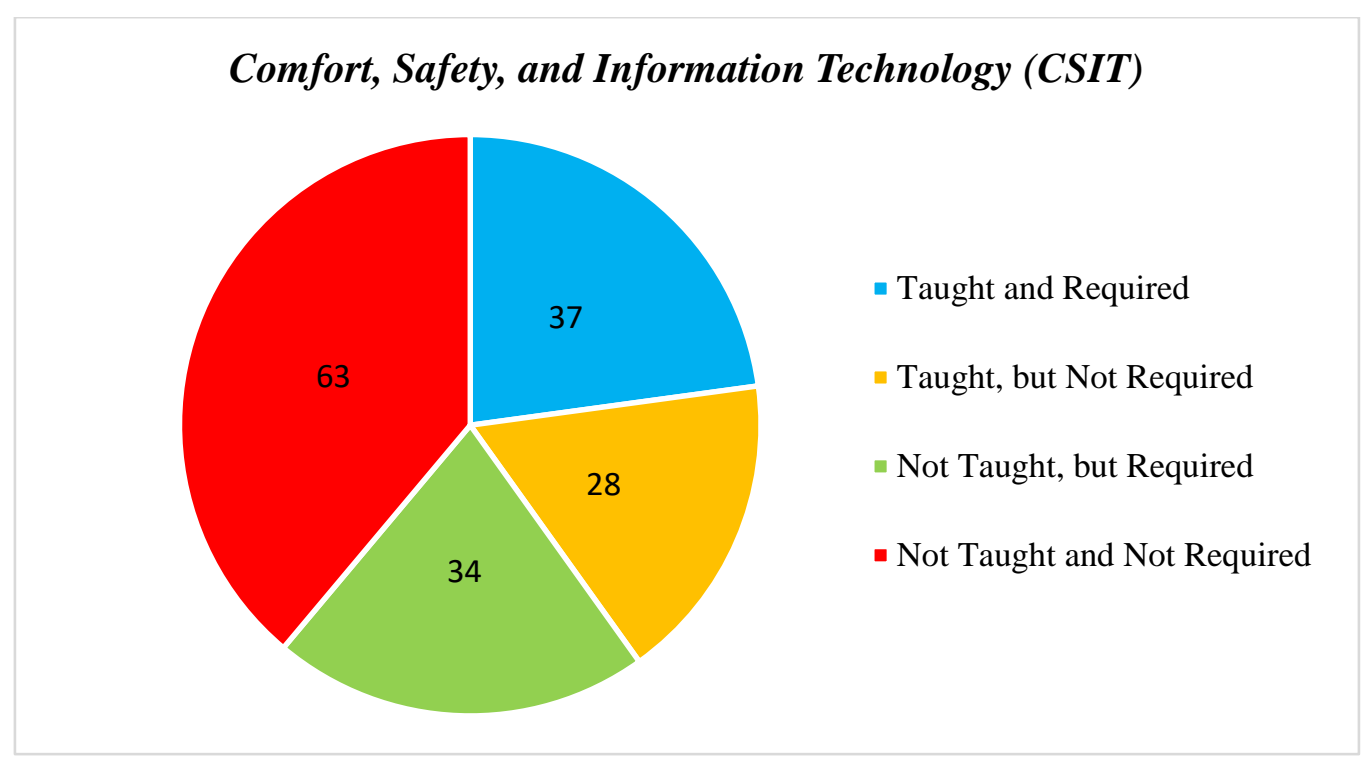

Figure 4. The Relevance of CSIT Cluster

There are 37 competencies of CSIT Cluster that are taught at SMK Ma'arif Salam and are required by the world of work. There are 28 competencies of CSIT Cluster that are taught at SMK Ma'arif Salam but are not required by the world of work. There are 34 competencies of CSIT Cluster that are not taught at SMK Ma'arif Salam but are required by the world of work. There are 63 competencies of CSIT Cluster that are not taught at SMK Ma'arif Salam and are not required by the world of work.

\section{Vehicle Control System (VCS) Cluster}

In the VCS cluster, there are 34 items of autotronic engineering competence that are taught in the AE Major of SMK Ma'arif Salam and are required by the world of work out of 49 competencies that are required by the world of work, with the relevance percentage of $27 \%$ from the $59 \%$ standard. Then, the VCS cluster was claimed to be relevant. Table 9 shows a breakdown of the VCS cluster autotronic engineering competencies that are taught in the AE Major at SMK Ma'arif Salam and are required by the world of work. Details of these competency items are presented in Figure 5.

Table 9. Details of VCS Cluster Relevance

\begin{tabular}{cll}
\hline No & \multicolumn{1}{c}{ Core Competencies } & \multicolumn{1}{c}{ Basic Competencies } \\
\hline 1 & Electric Control Unit (ECU) System & - Identifying components \\
& & - Understanding work principle \\
& & - Measuring components electric scale \\
& & - Diagnosing troubles \\
2 & In-Vehicle Networking System (IVNS) & - \\
3 & Fundamental Control System for Automotive (FCSA) & - \\
4 & Developing \& modifying Vehicle Control System (VCS) & - \\
\hline
\end{tabular}




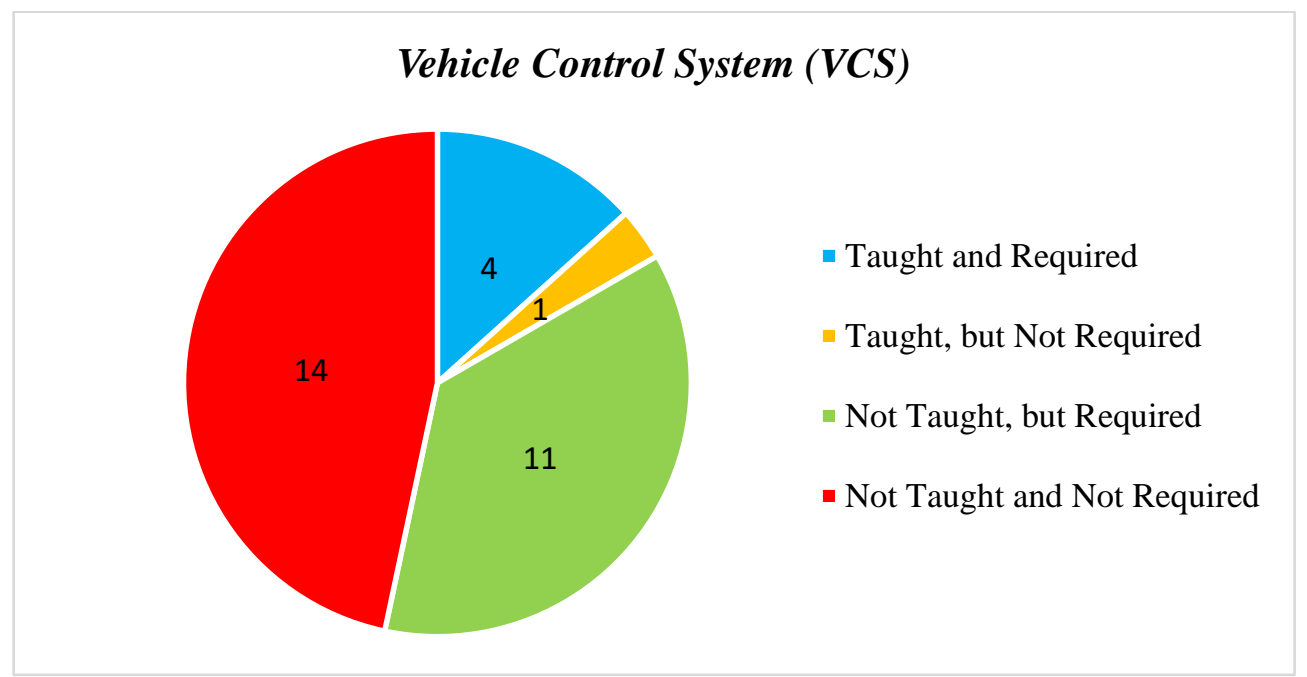

Figure 5. The Relevance of VCS Cluster

There are four competencies of VCS Cluster that are taught at SMK Ma'arif Salam and required by the world of work. There is one competency of VCS Cluster taught at SMK Ma'arif Salam but not required by the world of work. There are 11 competencies of VCS Cluster that are not taught at SMK Ma'arif Salam but required by the world of work. There are 14 competencies of VCS Cluster that are not taught at SMK Ma'arif Salam and not required by the world of work.

\section{Discussion}

The competency items in the 'not taught' category does not mean that they will not be taught onward, but one of the AE Major teachers said that the current condition of the SMK Ma'arif Salam (red. 2017-2020) does not allow the competency items that should be taught, to be taught optimally. So do the competency items in the 'not required' category, according to respondents from Suzuki Sleman and Mitsubishi Sleman, there are some competency items that are too high and difficult to master optimally by 'fresh graduates' from SMK AE Major. Thus, at the workshop of the Brand Holder Sole Agent (BHSA), the mechanic candidates will be given training to adjust the characteristics of the place they work later.

\section{CONCLUSION}

Based on INWCS, CC \& BC, and the INQF Schematic of Autotronic Engineering, the competency items of autotronic engineering are divided into five groups, as follows: (1) Support of Autotronic System (SA); (2) Engine Management System (EMS); (3) Chassis Management System (CMS); (4) Comfort, Safety, and Information Technology (CSIT); and (5) Vehicle Control System (VCS). Then, based on the results of the questionnaire checklist data analysis, each cluster containing 26, 90, 117, 162, and 90 competency items, obtained the following results.

At the profile of autotronic engineering competencies at SMK Ma'arif Salam, the items of competency taught there are: (1) SAS cluster of 15 competency items; (2) EMS cluster of 39 competency items; (3) CMS cluster of 63 competency items; (4) CSIT cluster of 65 competency items; and (5) VCS cluster of 5 competency items. At the profile of the autotronic engineering required by the world of work, the competency items required by the world of work are: (1) SAS cluster of 16 competency items; (2) EMS clusters of 49 competency items; (2) CMS cluster of 63 competency items; and (3) CSIT cluster of 71 competency items; and (5) VCS cluster of 15 competency items.

Furthermore, the results of the description of the relevance between the profile of autotronic engineering competencies at SMK Ma'arif Salam and the profile of autotronic engineering competencies required by the world of work, are: (1) in SAS cluster, 13 competency items are taught in Autotronic Engineering Major at SMK Ma'arif Salam and required by the world of work; (2) in EMS cluster, 34 competency items are taught in Autotronic Engineering Major at SMK Ma'arif 
Salam and required by the world of work; (3) in CMS clusters, 44 competcny items are taught in Autotronic Engineering Major at SMK Ma'arif Salam and required by the world of work; (4) in CSIT cluster, 37 competency items are taught in the Autotronic Engineering Major at SMK Ma'arif Salam and required by the world of work; and (5) in VCS cluster, four competency items are taught in Autotronic Engineering Major at SMK Ma'arif Salam and required by the world of work.

\section{REFERENCES}

Advanced Industries. (2013). The road to 2020 and beyond: What's driving the global automotive industry?. McKinsey \& Company.

Decree of the Director General of Primary and Secondary Education the Ministry of Education and Culture Number 330/D.D5/KEP/KR/2017 concerning the Core Competencies and Basic Competencies of the Subjects of National Content (A), Regional Content (B), Basic Field of Expertise (C1), Basic Program of Expertise (C2), and Expertise Competence (C3). (2017).

Decree of the Director General of Primary and Secondary Education of the Ministry of Education and Culture Number 4678/D/KEP/MK/2016 concerning the Vocational Secondary Education Competence Spectrum. (2016).

Fatullah, A., \& Ismara, K. I. (2018). Pengembangan trainer fluid level monitor berbasis Android untuk mata pelajaran Vehicle Control System (VCS) di SMK keahlian teknik ototronik. Jurnal Pendidikan Teknik Mekatronika, 8(3), 215-223. http://journal.student.uny.ac.id/ ojs/index.php/mekatronika/article/view/13096

Gagnon, R. (2009). Competency, meaningful learning and learning styles in TVET. In R. Maclean \& D. N. Wilson (Eds.), International handbook of education for the changing world of work - Bridging academic and vocational learning (pp. 2697-2712). Springer. https://doi.org/ 10.1007/978-1-4020-5281-1_XV.12.

Hollander, A., \& Mar, N. Y. (2009). Towards achieving TVET for all: The role of the UNESCOUNEVOC International Centre for Technical and Vocational Education and Training. In R. Maclean \& D. N. Wilson (Eds.). International handbook of education for the changing world of work - Bridging academic and vocational learning (pp. 41-57). Springer. https://doi.org/ 10.1007/987-1-4020-5281-1_3.

Indrawan, R., \& Yaniawati, P. (2016). Metodologi penelitian kuantitatif, kualitatif, dan campuran untuk manajemen, pembangunan, dan pendidikan. Refika Aditama.

International Labor Organization. (2015). Regional model competency standards: Core competencies. ILO Regional Office for Asia and the Pacific.

Jatmoko, D. (2013). Relevansi kurikulum SMK kompetensi keahlian Teknik Kendaraan Ringan terhadap kebutuhan dunia industri di Kabupaten Sleman. Jurnal Pendidikan Vokasi, 3(3), 113. https://doi.org/10.21831/jpv.v3i1.1572

Lauglo, J. (2009). Vocationalized secondary education. In R. Maclean \& D. N. Wilson (Eds.), International handbook of education for the changing world of work - Bridging academic and vocational learning (pp. 2295-2312). Springer. https://doi.org/10.1007/978-1-40205281-1_XIII.7

Lucas, B., Spencer, E., \& Claxton, G. (2012). How to teach vocational education: A theory of vocational pedagogy. The City and Guilds of London Institute.

MacKenzie J., \& Polvere R. A. (2009). TVET glossary: Some key terms. In R. Maclean \& D. N. Wilson (Eds.), International handbook of education for the changing world of work (pp. 5976). Springer. https://doi.org/10.1007/978-1-4020-5281-1_4 
Na, S. I. (2014). Relations between TVET system and employment. In Z. Zhao \& F. Rauner (Eds.), Areas of vocational education research: New frontiers of educational research (pp. 109125). Springer. https://doi.org/10.1007/978-3-642-54224-4_6

Newhouse, D., \& Suryadarma, D. (2009, September 1). The value of vocational education - High school type and labor market outcomes in Indonesia. Policy Research Working Paper.

Norton, R. E. (1997). DACUM handbook. The Ohio State University.

Priyatama, A. A., \& Sukardi, S. (2013). Profil kompetensi siswa SMK kompetensi keahlian Teknik Kendaraan Ringan di Kota Pekalongan. Jurnal Pendidikan Vokasi, 3(2), 153-162. https://doi.org/10.21831/jpv.v3i2.1593

Regulation of the Director General of Primary and Secondary Education of the Ministry of Education and Culture Number 06/D.D5/KK/2018 concerning Competence Spectrum of Vocational High School/Islamic Vocational High School. (2018).

Robert Bosch GmbH. (2007). Bosch automotive electrics and automotive electronics - Systems and components, networking and hybrid drive. Springer Vieweg.

Rojewski J. W. (2009). A conceptual framework for Technical and Vocational Education and Training. In R. Maclean \& D. N. Wilson (Eds.), International handbook of education for the changing world of work (pp. 19-39). Springer. https://doi.org/10.1007/978-1-4020-5281-1_2

Said, I. M., Sutadji, E., \& Sugandi, M. (2016). Pengembangan bahan ajar berbasis Cooperative Learning dengan pendekatan saintifik untuk siswa SMK se-Kota Malang program keahlian Teknik Ototronik. Jurnal Pendidikan, 1(2), 265-270. http://dx.doi.org/10.17977/jp.v1i2.6131

Sanghi, S. (2007). The handbook of competency mapping - Understanding, designing, and implementing competency models in organizations. Response Books.

Santoso, F. (2015). Efektivitas penerapan Quantum Teaching terhadap hasil belajar Elektronika Dasar pada siswa kelas X jurusan Teknik Ototronik SMK Negeri 1 Seyegan. Jurnal Elektronik Pendidikan Teknik Elektronika, 4(8), 25-38. http://journal.student.uny.ac.id/ojs/ index.php/elektronika/article/view/2058/1759

Sudira, P. (2016). TVET abad XXI - Filosofi, teori, konsep, dan strategi pembelajaran vokasional. UNY Press.

UNESCO-UNEVOC. (2015). World TVET Database - Indonesia. UNESCO.

Yudantoko, A., \& Arifin, Z. (2016). Profil kompetensi dunia kerja bidang perbaikan bodi otomotif dan tingkat relevansinya dengan dunia pendidikan. Jurnal Pendidikan Vokasi, 6(2), 127-142. https://doi.org/10.21831/jpv.v6i2.8334

Zhao Z. (2014). Competence research. In Z. Zhao \& F. Rauner (Eds.), Areas of vocational education research (pp. 167-188). New Frontiers of Educational Research, Springer. https://doi.org/10.1007/978-3-642-54224-4_9 